\title{
神学がモノを言う時
}

\section{Where theology matters}

\section{Nature Vol.432(657)/9 December 2004}

この数十年間で、今ほど宗教の声が目立つて聞かれ、影響力をもつことは なかった。宗教界に身を置く研究者であれ、世俗の研究者であれ、この現 実を受け入れる必要がある。ただし、神学者全員の支持が得られていない 教義も存在する点には留意すべきである。

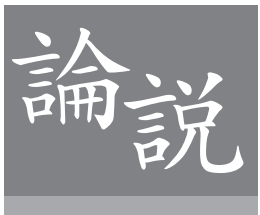

神学者と哲学者は、何世紀にもわたって宗教と科学の関 係について論争を続けてきた。もうこの局面に新たな展 開は期待できない。それに今から約 800 年前にトマス・ アクィナスが両者の折り合いをつける方法を見出してい る。そして 1930 年にはアインシュタインが「宇宙的な 宗教感情は、科学研究を行う動機として最も強固で高貴 なものである」と記した。これでよいではないか。科学 と宗教は「現実のそれぞれ異なる側面を明らかにしてい る」とするローマ教皇ヨハネ・パウロ二世の見方を素直 に受け入れようではないか。

その理由は、宗教と科学という2つの伝統が、いつも、 お互いの領域に迷い込んで問題を起こすからである。「天 地創造説」や「インテリジェントデザイン論」を学校で 教えることをめぐって巻き起こった政治闘争を考えてみ るとよい。これは、一部の宗教関係者が、自分たちの信 仰に科学の装いをさせて、他の人々にも押しつけょうと した動きだった。科学研究では、実験デー夕に基づいて 結論が導き出されるのであり、タルムードや聖書、コー ランの権威には頼らない。神の存在が科学の世界で認め られていないことに心を悩ませる人々がいるかもしれな いが、神の存在そのものや神の言うことに強制的に従っ
たとしても、それは歪んだ科学の世界を生み出すだけだ。

他方で科学は、産業界と手を結び、人間性に関しての 重大な問題を引き起こすような技術を導入して、宗教の 領域を侵害している。宗教界の思想家や世俗の倫理学者 が懸念を表明するのは正当な対応であり、科学者が、そ の声に耳を傾けずに研究に突き進むべきではない。将来 的には初期胚を破壊せずに幹細胞を取り出す方法が開発 されるかもしれないし、そうすれば今日の生命倫理に関 するホットなジレンマは解決されるだろう。しかし、そ の時には、また新たなジレンマが生まれることになる。

ユダヤ系の生命倫理学者で、生命倫理に関する米国大 統領諮問委員会の委員長を務めるレオン・カスは、問題 の核心に踏み込んで、こう語っている。「人間の死とい う問題を克服することが、現代医学の目標である。その ように表明されてはいないが、暗黙の了解が存在してい る」。永遠の命という課題は、これまで長い間、宗教の 領域に属していた。

医学は、苦しみを和らげることを目指している。これ は、確かに崇高な目標である。しかし宗教の世界では、 この目標を他のすべての価值に優先させるのは誤りだと 考えられている。カスは次のように語る。「医学の進歩 
とともに、死を克服しようという医学関係者の活動をま さに支えるような新たな倫理観が生まれた。すなわち、 命が助かるのならば、病気が治るのならば、あるいは死 を避けられるのであれば、何をしても許されるという見 方だ」。ほとんどの宗教宗派は、苦痛と死が不可避であ ることを受け入れ、単なる延命ではなく、命に意味合い を与えることを目指している。

また、宗教と科学は互いに異なる方法や基準を持つ。 「ヒト胚研究を推進する人々は、科学的に妥当と思われ る研究はすべて同時に推進すべきだと主張する。科学的 観点からすれば、この考元方が一番正しい。科学の世界 では、不確定性が認められれば、必要とされる研究をす べて行って必要な知識と理解を得ようとする。ただし、 科学にとってベストなことが、社会やその社会を構成す る人々にとってベストであるとは限らない」こう記し ているのは、ジョージタウン大学 (米国) で分子生物学 を研究するイエズス会の司祭 Kevin FitzGerald だ。

FitzGerald の研究では、倫理上許されないと判断し た実験を避けるょうにしている。これに対して、医学の 進歩がもたらされようとしている時に、もし一部の人々 が倫理性の問題を口にすれば、社会全体としての進歩も

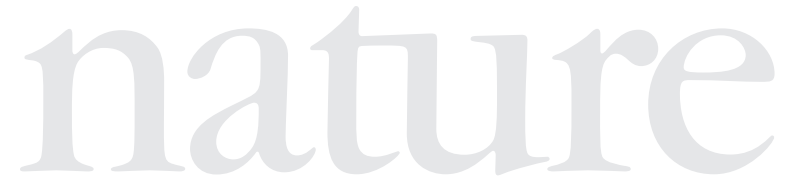

否定されなければならないのか、と考える人もいる。こ れが大きな問題となるのは、Nature 2004 年 12 月 9 号 p.666の news feature にあるように、この倫理観が一 部の神学者によって従来以上にあまりにも強い信念をも って主張される場合だ。たとえば、カトリック教徒のす べてが、ヒト胚の位置付けに関するローマ教皇庁の見解 によって胚性幹細胞研究は否定されるべきだと考えてい るわけではないのだ。

このような論争では、テレビ宣教師やバイオテクノロ ジー業界のロビイストによるレトリックがあふれており、 お互いに相手をく神を恐れぬフランケンシュタイン>、 <無知な熱狂的キリス卜教原理主義者 $>$ と風刺してい る。しかし生命倫理に関する大統領諮問委員会における 数々の証言を調べてみると、高い志に基づいた誠実な議 論がきちんと展開されていることに気がつく。

世俗の科学者(抢そらく多数派を形成すると思われる) は、この世の中、人間の苦痛、そして人間の死に意味付 けができるのは神のみだと考える人々の影響力や権利を 過小評価すべきではない。 